\title{
Two-step synthesis of di- and tristannylarenes from anilines via an $\mathrm{S}_{\mathrm{RN}} 1$ mechanism
}

\author{
Gustavo F. Silbestri, María T. Lockhart, and Alicia B. Chopa* \\ Instituto de Química del Sur (CONICET - UNS), Departamento de Química, Universidad \\ Nacional del Sur, Avenida Alem 1253, Bahía Blanca, B8000CPB, Argentina \\ E-mail:abchopa@uns.edu.ar
}

Dedicated to Profs. Oscar Giordano, Rita Hoyos de Rossi, Manuel González Sierra and Julio Podestá, for their invaluable contributions to organic chemistry

\begin{abstract}
The synthesis in good yields (71-85\%) of di- and tristannylated benzenes from commercially available anilines, involving their conversion to the corresponding aryltrimethylammonium salts followed by the reaction with $\mathrm{Me}_{3} \mathrm{SnNa} 1$ in liquid ammonia, is described. The results obtained clearly indicate that the stannylation reactions proceed through an $\mathrm{S}_{\mathrm{RN}} 1$ mechanism.
\end{abstract}

Keywords: Aryltin, $\mathrm{S}_{\mathrm{RN}} 1$, arylammonium salts

\section{Introduction}

The synthesis of organotin compounds and their application as intermediates has become a very important aspect in organic chemistry. ${ }^{1}$ In particular, aryltin compounds are versatile intermediates because of their high reactivity towards different electrophiles. For example, Pdcatalyzed cross-coupling of aryltin compounds with carbon electrophiles (the Stille reaction) is widely employed for $\mathrm{C}-\mathrm{C}$ bond formation owing to its versatile nature, great functional group toleration and better yields. ${ }^{2}$ In most cases, substrates supporting only one organotin moiety have been employed. Although di- and tristannylated substrates would be interesting intermediates in organic synthesis, there are few and relatively limited methods available for the synthesis of such compounds, most of them using haloarenes as starting materials. Thus, it has been reported the synthesis of 1,3- (58\%) and 1,4-bis(tributylstannyl)benzene $(67 \%)^{3 \mathrm{a}}$ as well as 1,3,5-tris(trimethylstannyl)benzene $(69 \%)^{3 \mathrm{~b}}$ by reaction of the corresponding di- or trilithiobenzene with $\mathrm{Bu}_{3} \mathrm{SnCl}$ or $\mathrm{Me}_{3} \mathrm{SnCl}$, respectively.

On the other hand, Wursthorn and Kuivila reported that the reaction of 1,2-dibromobenzene with $\mathrm{Me}_{3} \mathrm{SnNa} 1$ in tetraglyme (TG) afforded the disubstitution product in $42 \%$ yield. ${ }^{4}$ Also, it 
has been reported that the reaction of 1,3,5-tribromobenzene with an excess of $\mathbf{1}$, in the same solvent, gave the corresponding trisubstituted product in $89 \%$ yield. $^{5}$

In addition, Rossi has found that the photostimulated reaction of 1,2-, 1,3- and 1,4dichlorobenzenes as well as 1,3,5-trichlorobenzene with an excess of $\mathrm{Me}_{3} \mathrm{SnNa} 1$ in liquid ammonia, afforded the corresponding di- and tristannylated products in 58, 90, 88 and $71 \%$ yield, respectively. ${ }^{6}$ It should be mentioned that the reactions performed with 1,2- and 1,3,5chlorobenzenes rendered also high amounts of the related protodestannylated products ( 35 and $20 \%$, respectively).

In connection with the synthetic importance of organotin compounds, we are involved in searching new routes for their synthesis starting from inexpensive and commercially available materials. ${ }^{7}$ For example, we have synthesized mono-, bi- and tristannylbenzenes by the reaction of different aryl diethyl phosphates with organostannides. ${ }^{7 \mathrm{~d}}$ Moreover, we have demonstrated that monostannylarenes could be synthesized, in excellent yields, from anilines via the reaction of their trimethylammonium salts with organostannides, in liquid ammonia, by an $\mathrm{S}_{\mathrm{RN}} 1$ mechanism. ${ }^{7 b}$ It is important to note that this alternative route to the synthesis of organostannanes avoids the use of Grignard reagents or organolithium compounds.

In this work we describe the results obtained from the reaction of a series of aryltrimethylammonium salts, supporting more than one leaving group, with $\mathrm{Me}_{3} \mathrm{SnNa} 1$ in liquid ammonia.

\section{Results and Discussion}

From inexpensive and commercially available anilines, we prepared, by known procedures, ${ }^{8}$ diverse arylammonium salts.<smiles>C[N+](C)(C)c1cccc(Cl)c1</smiles>

$2^{a}$<smiles>C[N+](C)(C)c1ccc(Cl)cc1</smiles>

$2^{b}$

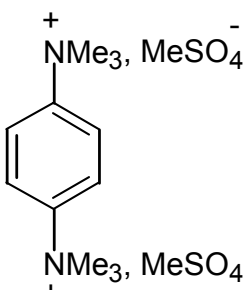

${ }_{2} \mathrm{C}$

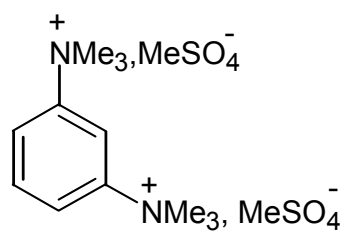

${ }_{2}^{d}$<smiles>CCN(C)c1ccccc1C</smiles><smiles>C[N+](C)(C)c1cc(Cl)cc(Cl)c1</smiles>

$3^{a}$<smiles>CN(c1ccc([N+](C)(C)C)cc1Cl)S(C)(=O)=O</smiles>

$3^{b}$ 
At first, we examined the reactivity of those salts containing two nucleofugal groups toward $\mathrm{Me}_{3} \mathrm{SnNa}$ in liquid ammonia. The results obtained are summarized in Table 1.

Table 1. Reactions of arylammonium salts 2 a-d with $\mathrm{Me}_{3} \mathrm{SnNa}$ in liquid ammonia

2a: $\mathrm{Z}=3-\mathrm{Cl}$

2b: $\mathrm{Z}=4-\mathrm{Cl}$

2c: $\mathrm{Z}=4-\mathrm{NMe}_{3}{ }^{+}$

2d: $\mathrm{Z}=3-\mathrm{NMe}_{3}{ }^{+}$
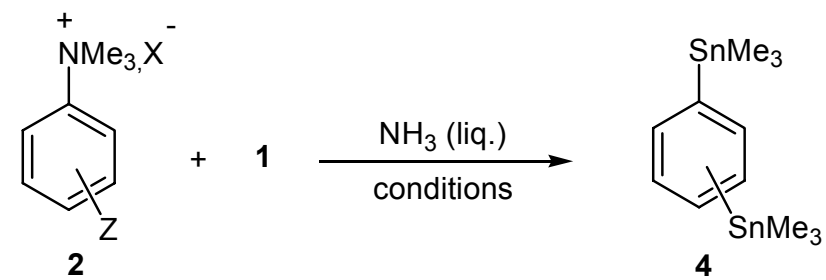

\begin{tabular}{|c|c|c|c|c|}
\hline Entry & Substrate & $\begin{array}{c}\text { Molar } \\
\text { Ratio 1:2 }\end{array}$ & Conditions, Time (min) & Product, Yield $(\%)^{\mathrm{a}}$ \\
\hline 1 & $\mathbf{2 a}$ & $2.4: 1$ & hvv, 30 & $\mathbf{4 a}\left(3-\mathrm{SnMe}_{3}\right), 85$ \\
\hline 2 & $\mathbf{2 a}$ & $2.4: 1$ & dark, 30 & $\mathbf{4 a}, 14$ \\
\hline 3 & $\mathbf{2 a}$ & $2.4: 1$ & dark, $20 \% p$-DNB, 30 & $4 \mathbf{a}, \quad 0$ \\
\hline 4 & $2 \mathbf{b}$ & $2.4: 1$ & $\mathrm{~h} v, 30$ & 4b $\left(4-\mathrm{SnMe}_{3}\right), 76$ \\
\hline 5 & $2 \mathbf{b}$ & $2.4: 1$ & dark, 30 & $\mathbf{4 b}, 12$ \\
\hline 6 & $2 b$ & $2.4: 1$ & dark, $20 \% p$-DNB, 30 & $4 b, \quad 0$ \\
\hline 7 & $2 c$ & $2.4: 1$ & $\mathrm{~h} v, 60$ & $4 b, 50^{b}$ \\
\hline 8 & $2 c$ & $3: 1$ & $h v, 60$ & $\mathbf{4 b}, 71$ \\
\hline 9 & $2 c$ & $6: 1$ & $h v, 60$ & $4 b, 74$ \\
\hline 10 & $2 c$ & $3: 1$ & dark, 60 & $4 b, 20$ \\
\hline 11 & $2 c$ & $3: 1$ & dark, $20 \% p$-DNB, 30 & $4 b, 0$ \\
\hline 12 & $2 d$ & $3: 1$ & $\mathrm{~h} v, 60$ & $4 a, 84$ \\
\hline 13 & $2 d$ & $3: 1$ & dark, 60 & $4 a, 0$ \\
\hline
\end{tabular}

${ }^{a}$ Yield of isolated products. ${ }^{b}$ Together with unidentified products

The photostimulated reaction of 3-chlorophenyltrimethylammonium iodide $\mathbf{2 a}$ with $\mathrm{Me}_{3} \mathrm{SnNa} 1$ proceeded efficiently (30 min, 1/2.4) to afford 1,3-bis(trimethylstannyl) benzene $\mathbf{4 a}^{9}$ in $85 \%$ yield (entry 1). We found that there was a slow reaction in the dark which was completely inhibited by the addition of $p$-dinitrobenzene ( $p$-DNB, 20\%) a well-known inhibitor of radical anions ${ }^{10}$ (entries $2 \& 3$ ). These results clearly indicate that the reaction goes through an $\mathrm{S}_{\mathrm{RN}} 1$ mechanism, as shown in Scheme 1, and that there is a spontaneous electron transfer (ET) which is stimulated under irradiation. It is important to note that in the dark reaction there were also detected traces of 3-chlorophenyltrimethylstannane, i.e., evidence that the trimethylamino group was the first nucleofuge replaced in the reaction. Nevertheless, under irradiation, even at really short reaction times $(10 \mathrm{sec})$ no monosubstitution products were detected and only $4 \mathbf{a}$ was 
present in tiny amounts (GC/MS). It should be mentioned that starting substrate was detected in the aqueous phase. ${ }^{11}$ Disubstitution without accumulation of monosubstituted products could be attributed to the preferential expulsion of the nucleofuge from the intermediate radical anion to form the corresponding monostannylated phenyl radical rather than SET to substrate (Scheme 1).

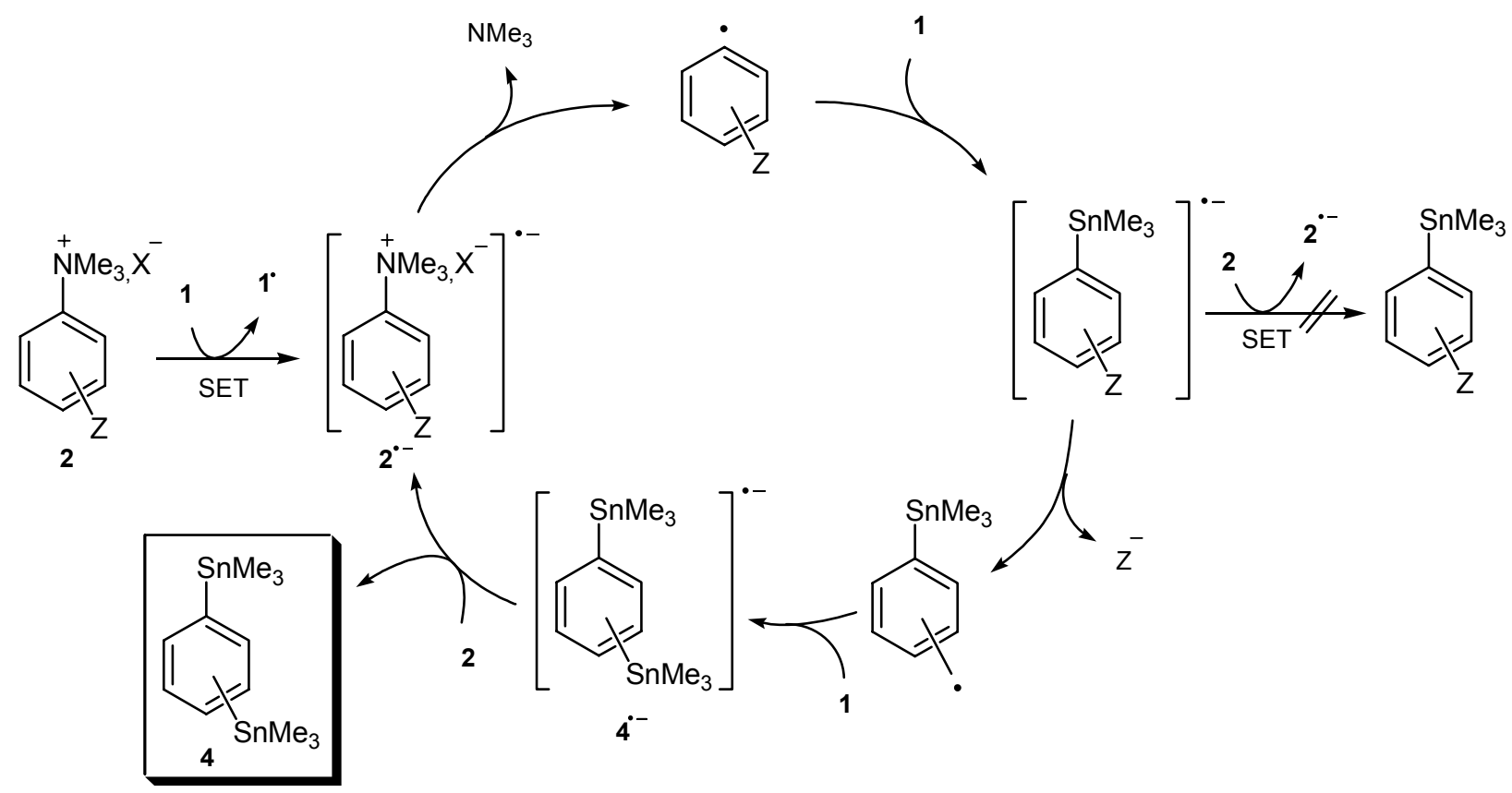

Scheme 1. Proposed mechanistic pathways in the $\mathrm{S}_{\mathrm{RN}} 1$ reactions of $\mathbf{2 a - d}$ with $\mathrm{Me}_{3} \mathrm{SnNa} 1$ in liquid ammonia.

As we reported in a preliminary communication, similar results have been obtained in the reactions carried out with 4-chlorophenyltrimethylammonium iodide $\mathbf{2 b}$ (entries 4 to 6). Under irradiation, the disubstitution product, i.e., 1,4-bis(trimethylstannyl)benzene $\mathbf{4 b}$ was obtained in $76 \%$ yield. $^{7 \mathrm{~b}}$

We considered interesting to study the reaction of the 2-chlorophenyltrimethylammonium salt with 1. Unfortunately, we were not able to synthesize this salt; although we used different conditions the reaction always stopped at the tertiary amine stage.

Next, we performed reactions with substrates supporting two trimethylamino groups. Thus, the photostimulated reaction of hexamethyl-1,4-phenylenediaminium bis(methyl sulfate) $2 \mathbf{c}$ with $\mathrm{Me}_{3} \mathrm{SnNa} 1(1 / 2.4)$ gave, after $60 \mathrm{~min}$, only $50 \%$ of $\mathbf{4 b}$ (entry 7). In order to increase its yield we performed experiments 8 and 9, using an excess of 1 ( 3 and 6 equiv, respectively) and we found that, under both reaction conditions, the yield of $\mathbf{4 b}$ was increased, rendering similar results ( 71 and $74 \%$ yield, respectively). So, we considered that 3 equiv of 1 are enough to achieve our goal. On the other hand, experiments 10 and 11 showed that there was also a spontaneous ET in the dark reaction, which is totally inhibited by the addition of $p$-DNB (20\%). 
Moreover, the photostimulated reaction of 1,3-isomer 2d with $\mathrm{Me}_{3} \mathrm{SnNa} 1$ (1/3) gave the distannylated product 4a in high yield (84\%) (entry 12). It should be mentioned that there was no spontaneous ET and that the starting substrate was the only compound detected in the dark reaction. ${ }^{11}$ In addition, either with $\mathbf{2 c}$ or $\mathbf{2 d}$, no monosubstitution product was detected even at shorter times. ${ }^{11}$

It should be mentioned that the exhaustive methylation of 1,2-phenylenediamine gave 2-(dimethylamino)phenyltrimethylammonium methyl sulfate 2e. Thus, it was not possible to generate the diammonium salt, probably due to steric hindrance. We performed the reaction of $2 \mathbf{e}$ with 1 (1/1.2) and, surprisingly, the reaction gave the demethylated product 1,2tetramethylphenylenediamine, probably generated by the nucleophilic attack of $\mathrm{Me}_{3} \mathrm{SnNa} 1$ to the methyl carbon, instead of the expected stannyl derivative, formed by a $\mathrm{S}_{\mathrm{RN}} 1$ reaction on the aromatic ring. The detection of $\mathrm{Ph}_{3} \mathrm{SnMe}(\mathrm{GC} / \mathrm{MS})$ in the reaction of $2 \mathbf{e}$ with triphenyltin anion confirmed our hypothesis, that is, the prevalence of nucleophilic aliphatic substitution. We cannot explain the special reactivity shown by $2 \mathbf{e}$ towards $\mathbf{1}$.

From the above mentioned results it is evident that the reactions of $\mathbf{2 a}$ to $\mathbf{2 d}$ with $\mathbf{1}$ take place through an $\mathrm{S}_{\mathrm{RN}} 1$ mechanism without intermediacy of a monosubstitution product, as is sketched in Scheme 1. Moreover, the reactions are really efficient for the synthesis of 1,3- and 1,4distannylbenzenes. It should be noted that the coupling with the nucleophile is not the only reaction that aryl radicals can undergo: hydrogen atom transfer from the solvent is one of the most important side reactions. This competitive reaction, which would give trimethylstannylbenzene as side product, is prevented by using liquid ammonia as solvent, which is a poor hydrogen atom donor. As far as we know, there are no bibliographic reports in connection with the substitution of two $-\mathrm{NMe}_{3}$ groups -both attached to the benzene ring- by a single-stage bis- $\mathrm{S}_{\mathrm{RN}} 1$ mechanism.

Then, with the aim of synthesizing tristannylated derivatives, we studied the reaction of $\mathbf{1}$ with substrates 3a and $\mathbf{3 b}$, bearing three nucleofugal groups. The substrates were selected based on their low cost and commercial availability. The photostimulated reaction $(60 \mathrm{~min})$ of 3,5dichlorophenyltrimethylammonium methyl sulfate 3a with $\mathrm{Me}_{3} \mathrm{SnNa} \mathbf{1}$ (Table 2, entry 1) gave the desired trisubstitution product $5^{9}$ together with $\mathbf{4 a}$ in a $3 / 1$ ratio (GC). A major excess of $\mathbf{1}$ (6 equiv) did not increase the percentage of 5 in the product mixture. It should be emphasized that it is possible to recuperate $\mathbf{5}$ almost quantitatively from the mixture, by recrystallization in EtOH. When the reaction was quenched at $5 \mathrm{~min}, 25 \%$ GC yield of 5 was obtained together with $\mathbf{4 a}$ in a $2.5 / 1$ ratio. No monosubstitution products were detected either in the organic or in the deuterium oxide phase.

In a dark reaction, 3,5-dichlorophenyltrimethylstannane was detected (confirming that the trimethylamino group is the first nucleofuge replaced) together with tiny amounts of $\mathbf{5}$ and $\mathbf{4 a}$ (GC/MS). In addition, in the deuterium oxide layer, the existence of the dehalogenation product 2a was confirmed by ${ }^{13} \mathrm{C}$ NMR. When we performed a dark reaction with the addition of $p$-DNB $(20 \%)$, no stannylated products were formed and $\mathbf{2 a}$ was the only compound detected by ${ }^{1} \mathrm{H}$ and ${ }^{13} \mathrm{C}$ NMR.${ }^{11}$ These results suggest the co-existence of two mechanisms: halogen-metal exchange 
(HME) and $\mathrm{S}_{\mathrm{RN}} 1$. On one hand, through $\mathrm{HME}$ an intermediate anion is generated whose protonation by ammonia gives 2a; under irradiation, 2a reacts with $\mathrm{Me}_{3} \mathrm{SnNa} 1$ giving 4a (Scheme 2). Simultaneously, through an $\mathrm{S}_{\mathrm{RN}} 1$ mechanism, similar as that sketched in Scheme 1, the tristannylated product 5 is formed. This would explain the ratio of $\mathbf{5 / 4 a}$ present in the crude product whatever the excess of $\mathbf{1}$ used. Moreover, the fact that higher amounts of $\mathbf{5}$ were obtained under irradiation indicates that, under these reaction conditions, $\mathrm{S}_{\mathrm{RN}} 1$ competes efficiently with HME.

Table 2. Reactions of 3a with $\mathrm{Me}_{3} \mathrm{SnNa} 1$ in liquid ammonia

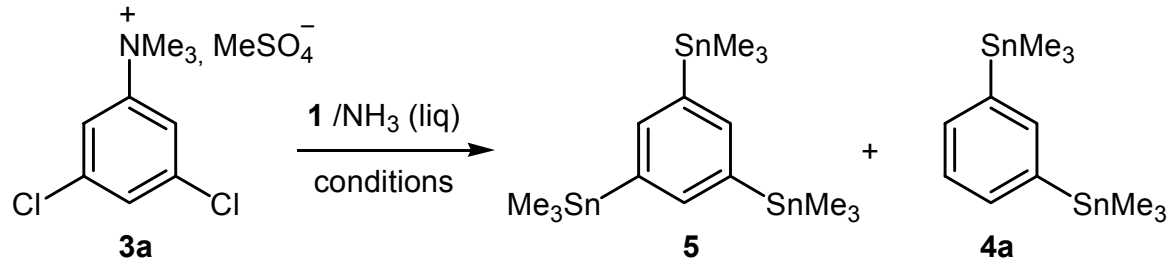

\begin{tabular}{ccccc}
\hline Entry & $\begin{array}{c}\text { Molar } \\
\text { Ratio } \\
\mathbf{1 : 3 a}\end{array}$ & Conditions,Time (min) & $\begin{array}{c}\mathbf{5} \\
\text { Yield (\%) }\end{array}$ & $\mathbf{5 : 4 a}^{\mathrm{a}}$ \\
\hline 1 & $3.6: 1$ & $\mathrm{~h} v, 60$ & $72^{\mathrm{b}}$ & $3: 1$ \\
2 & $6: 1$ & $\mathrm{~h} v, 60$ & $73^{\mathrm{b}}$ & $3: 1$ \\
3 & $3.6: 1$ & $\mathrm{~h} v, 5$ & $25^{\mathrm{c}}$ & $2.5: 1$ \\
4 & $3.6: 1$ & dark, 30 & $\mathrm{~d}$ & - \\
5 & $3.6: 1$ & dark, $20 \% p$-DNB, 30 & 0 & - \\
\hline
\end{tabular}

${ }^{a}$ Relative abundance ratios determined by GC. ${ }^{b}$ Isolated pure product. ${ }^{c}$ Determined by GC. ${ }^{\mathrm{d}}$ Observed by GC/MS.

As sketched in Scheme 3, photoestimulated reaction (30 min) of $\mathbf{3 b}$ with $\mathrm{Me}_{3} \mathrm{SnNa} 1$ (3b/1, 1/3.6) proceeded rendering 1,4-bis(trimethylstannyl)benzene $\mathbf{4 b}$, as unique product, in $85 \%$ yield. A similar reaction quenched at short time $(5 \mathrm{~min}$ ) gave $\mathbf{4 b}$ in $55 \%$ yield together with $\mathbf{2 c}$ which was detected by ${ }^{13} \mathrm{C}$-NMR in the deuterium oxide phase. ${ }^{11}$ The dark reaction gave higher amounts of the dehalogenation product $2 \mathbf{c}$ (deuterium oxide phase) together with $\mathbf{4 b}$ in $c a .10 \%$ yield. No starting substrate was detected. Next, we performed a similar dark reaction but in the presence of $p$-DNB; it was only detected the dehalogenation product $2 \mathbf{c}$. These results suggest the occurrence of a fast HME reaction, in which 1 reacts with the substrate by nucleophilic displacement on halogen, followed by the protonation of the intermediate anion by ammonia to give 2c which slowly reacts with $\mathrm{Me}_{3} \mathrm{SnNa} 1$ in the dark through a spontaneous ET reaction. Under irradiation $\mathbf{2 c}$ reacts with $\mathbf{1}$ giving high yields of $\mathbf{4 b}$ through an $\mathrm{S}_{\mathrm{RN}} 1$ mechanism. The fact that no monosubstitution product was found indicates that the intermediate anion does not react with $\mathrm{Me}_{3} \mathrm{SnCl}$ in liquid ammonia (Scheme 3). 

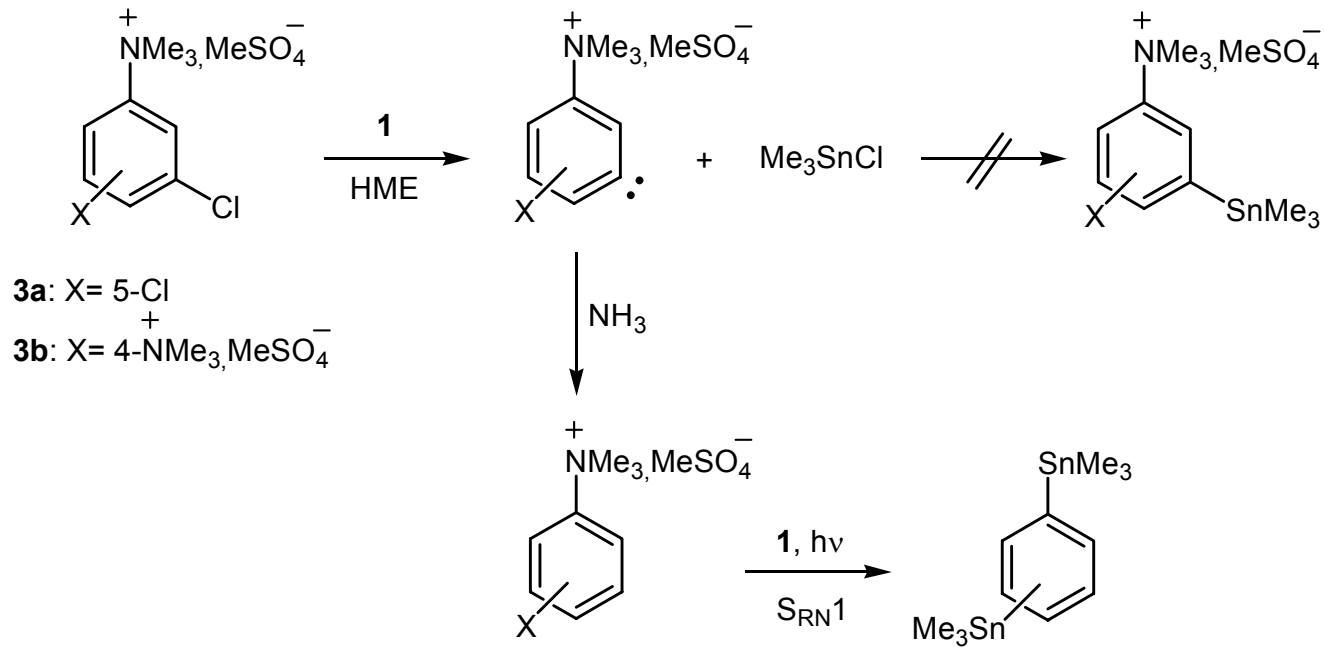
2a: $\mathrm{X}=3-\mathrm{Cl}$
4a: $3-\mathrm{SnMe}_{3}$
2c: $\mathrm{X}=4-\mathrm{NMe}_{3}, \mathrm{MeSO}_{4}$
4b: $4-\mathrm{SnMe}_{3}$

Scheme 2. Mechanistic proposal for the generation of $\mathbf{4 a}$ and $\mathbf{4 c}$ from $\mathbf{3 a}$ and $\mathbf{3 b}$.
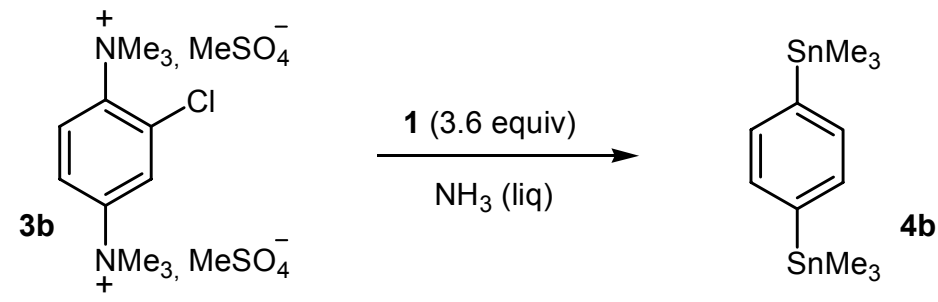

$\mathrm{h} v, 30 \mathrm{~min}$
$\mathrm{~h} v, 5 \mathrm{~min}$
dark, $30 \mathrm{~min}$
dark, $20 \% p$-DNB, $30 \mathrm{~min}$

$85 \%$

$55 \%$

$10 \%^{a}$

dark, $20 \% p$-DNB, 30 min

$0 \% \mathrm{~b}$

Scheme 3. Reactivity of $\mathbf{3 b}$ towards $\mathrm{Me}_{3} \mathrm{SnNa} 1$ in liquid ammonia. ${ }^{\mathrm{a}}$ Together with ca.85\% of 2c. ${ }^{\mathrm{b}} \mathbf{2 c}$ the only product.

\section{Conclusions}

We have demonstrated the synthesis of distannylbenzenes starting from chloroanilines or phenylenediamines, by their conversion to the corresponding trimethylammonium salts followed by the displacement reaction with trimethyltin anion in liquid ammonia. Our studies support that these reactions go via an $\mathrm{S}_{\mathrm{RN}} 1$ mechanism. Furthermore, we identify two competing mechanisms, $\mathrm{HME}$ and $\mathrm{S}_{\mathrm{RN}} 1$, in the reactions performed with the arylammonium salts supporting three nucleofuges. Thus, it was only possible the synthesis of 1,3,5- 
tris(trimethylstannyl)benzene. It should be mentioned that, as far as we know, there are few reports of trisubstitution reactions through an $\mathrm{S}_{\mathrm{RN}} 1$ mechanism: besides those mentioned above ${ }^{6 b, 7 \mathrm{~d}}$ is included the photostimulated reaction of 1,3,5-trichloro and tribromo benzenes with $\mathrm{Co}(\mathrm{OAc})_{2}$ and $\mathrm{CO} .^{12}$

\section{Experimental Section}

General. Irradiation was conducted in a reactor made of Pyrex, equipped with four $250 \mathrm{~W} \mathrm{UV}$ lamps emitting maximally at $350 \mathrm{~nm}$ (Philips Model HPT, water-refrigerated). All manipulations were performed under nitrogen or argon. The solvents used were dried and distilled in accordance with standard procedures. Melting points were determined on a Reichert-Koefler hotstage microscope. NMR spectra were recorded in $\mathrm{CDCl}_{3}$ and $\mathrm{D}_{2} \mathrm{O}$ on a $300 \mathrm{MHz}$ spectrometer (300.1 MHz for ${ }^{1} \mathrm{H}, 75.5 \mathrm{MHz}$ for ${ }^{13} \mathrm{C}$ ) at $23{ }^{\circ} \mathrm{C}$. Mass spectra were obtained with a GC/MS instrument (HP5-MS capillary column, $30 \mathrm{~m} \times 0.25 \mathrm{~mm} \times 0.25 \mu \mathrm{m}$ ) equipped with 5972 mass selective detector operating at $70 \mathrm{eV}$ (EI). Aryltrimethylammonium salts $\mathbf{2 a - 2 e}$ and $\mathbf{3 b}$ were prepared by the method of Sommer; ${ }^{8 a, b}$ 3a was prepared by reaction of 3,5-dichlorophenyldimethylamine with $\mathrm{Me}_{2} \mathrm{SO}_{4}$ in DMF at room temperature; starting dimethyl amine was synthesized by the method of Giumanini. ${ }^{8 c}$ They were characterized by their physical and NMR spectroscopic data. Dark reactions were performed in a reaction flask wrapped with aluminum foil.

\section{Preparation of aryltrimethylammonium salts}

3-Chlorophenyltrimethylammonium iodide (2a). ${ }^{13}$ Purification by crystallization from acetone gave the title compound as a colorless solid in $84 \%$ yield; m.p.: $176-178{ }^{\circ} \mathrm{C} ;{ }^{1} \mathrm{H}$ NMR $\left(\mathrm{D}_{2} \mathrm{O}\right): \delta$ $8.03(\mathrm{~m}, 1 \mathrm{H}), 7.84(\mathrm{~m}, 1 \mathrm{H}), 7.68(\mathrm{~m}, 2 \mathrm{H}), 3.70(\mathrm{~s}, 9 \mathrm{H}) ;{ }^{13} \mathrm{C}$ NMR: $\delta 147.8(\mathrm{C}), 135.9(\mathrm{C}), 132.2$ $(\mathrm{CH}), 131.3(\mathrm{CH}), 121.1(\mathrm{CH}), 118.9(\mathrm{CH}), 57.7\left(\mathrm{CH}_{3}\right)$.

$N, N, N, N^{\prime}, N$, $N$ '-Hexamethyl-1,4-phenylenediaminium bis(methyl sulfate) $(2 \mathrm{c}) .{ }^{14}$ Purification by crystallization from acetone gave the title compound as a colorless solid in $62 \%$ yield; m.p.: 230-232 ${ }^{\circ} \mathrm{C} ;{ }^{1} \mathrm{H}$ NMR $\left(\mathrm{D}_{2} \mathrm{O}\right): \delta 8.16(\mathrm{~s}, 4 \mathrm{H}), 3.76(\mathrm{~s}, 6 \mathrm{H}), 3.74(\mathrm{~s}, 18 \mathrm{H}) ;{ }^{13} \mathrm{C}$ NMR: $\delta 148.0(\mathrm{C})$, $123.1(\mathrm{CH}), 57.6\left(\mathrm{CH}_{3}\right), 55.9\left(\mathrm{CH}_{3}\right)$.

$N, N, N, N$, $N$, $N$ '-Hexamethyl-1,3-phenylenediaminium $\quad$ bis(methyl $\quad$ sulfate) $\quad(2 \mathrm{~d}){ }^{15}$ Purification by crystallization from acetone gave the title compound as a colorless solid in $73 \%$ yield; m.p.: $156-158{ }^{\circ} \mathrm{C} ;{ }^{1} \mathrm{H}$ RNMR $\left(\mathrm{D}_{2} \mathrm{O}\right): \delta 8.28(\mathrm{~m}, 1 \mathrm{H}), 8.20(\mathrm{~m}, 2 \mathrm{H}), 8.00(\mathrm{~m}, 1 \mathrm{H}), 3.79(\mathrm{~s}$, $18 \mathrm{H}), 3,76(\mathrm{~s}, 6 \mathrm{H}) ;{ }^{13} \mathrm{C}$ NMR: $\delta 148.2(\mathrm{C}), 133.5(\mathrm{CH}), 123.1(\mathrm{CH}), 113.4(\mathrm{CH}), 57.8\left(\mathrm{CH}_{3}\right)$, $55.9\left(\mathrm{CH}_{3}\right)$.

2-(Dimethylamino)phenyltrimethylammonium iodide (2e). Purification by crystallization from acetone gave the title compound as a violet solid in $85 \%$ yield; m.p.: $175-177{ }^{\circ} \mathrm{C} ;{ }^{1} \mathrm{H}$ NMR $\left(\mathrm{D}_{2} \mathrm{O}\right): \delta 8.38-8.30(\mathrm{~m}, 1 \mathrm{H}), 7.76-7.56(\mathrm{~m}, 3 \mathrm{H}), 3.02(\mathrm{~s}, 9 \mathrm{H}), 2.77(\mathrm{~s}, 6 \mathrm{H}),{ }^{13} \mathrm{C}$ NMR: $\delta 253.5$ (C), $148.6(\mathrm{C}), 142.8(\mathrm{CH}), 130.2(\mathrm{CH}), 125.3(\mathrm{CH}), 122.6(\mathrm{CH}), 46.8\left(\mathrm{CH}_{3}\right), 19.4\left(\mathrm{CH}_{3}\right)$. 
3,5-Dichlorophenyltrimethylammonium methyl sulfate (3a). ${ }^{16}$ Purification by crystallization from acetone gave the title compound as a colorless solid in $74 \%$ yield; m.p.: $168-170{ }^{\circ} \mathrm{C} ;{ }^{1} \mathrm{H}$ $\operatorname{NMR}\left(\mathrm{D}_{2} \mathrm{O}\right): \delta 7.97(\mathrm{~s}, 2 \mathrm{H}), 7.74(\mathrm{~s}, 1 \mathrm{H}), 3.76(\mathrm{~s}, 3 \mathrm{H}), 3.71(\mathrm{~s}, 9 \mathrm{H}) ;{ }^{13} \mathrm{C}$ NMR: $\delta 148.2(\mathrm{C}), 136.7$ (C), $131.3(\mathrm{CH}), 120.0(\mathrm{CH}), 57.7\left(\mathrm{CH}_{3}\right), 55.8\left(\mathrm{CH}_{3}\right)$.

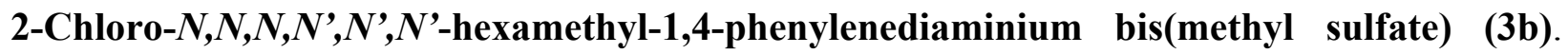
Purification by crystallization from methanol gave the title compound as a violet solid in $61 \%$ yield; m.p.: 218-220 ${ }^{\circ} \mathrm{C} ;{ }^{1} \mathrm{H}$ NMR $\left(\mathrm{D}_{2} \mathrm{O}\right): \delta 8.40-8.09(\mathrm{~m}, 3 \mathrm{H}), 3.94(\mathrm{~s}, 9 \mathrm{H}), 3.76(\mathrm{~s}, 6 \mathrm{H}), 3.75(\mathrm{~s}$, 9H); ${ }^{13} \mathrm{C}$ NMR: $\delta 148.5(\mathrm{C}), 143.3(\mathrm{C}), 129.2(\mathrm{C}), 127.7(\mathrm{CH}), 125.5(\mathrm{CH}), 121.5(\mathrm{CH}), 57.6$ $\left(\mathrm{CH}_{3}\right), 56.9\left(\mathrm{CH}_{3}\right), 55.9\left(\mathrm{CH}_{3}\right)$.

Representative procedure for photostimulated reactions in liquid ammonia: synthesis of 1,4-bis(trimethylstannyl)benzene (4b)

In a $250 \mathrm{~mL}$ two-necked round-bottomed flask, equipped with a cold finger condenser charged with acetone-liquid nitrogen, a nitrogen inlet and magnetic stirrer were condensed $180 \mathrm{~mL}$ of Na-dried ammonia. $\mathrm{Me}_{3} \mathrm{SnCl}(0.60 \mathrm{~g}, 3.0 \mathrm{mmol})$ was dissolved and sodium metal $(0.158 \mathrm{~g}, 6.8$ mmol) was added until the blue color persisted for at least $5 \mathrm{~min}$. When the blue color disappeared, hexamethyl-1,4-phenylenediaminium bis(methyl sulfate) 2c (1.0 mmol, $0.416 \mathrm{~g}$ ) was added and the solution was irradiated with stirring for 1 hour. The reaction was quenched with $\mathrm{NH}_{4} \mathrm{Cl}, 10 \mathrm{~mL}$ of $\mathrm{Et}_{2} \mathrm{O}$ was added and then liquid ammonia was allowed to evaporate. The resultant solution was treated with water and extracted with $\mathrm{Et}_{2} \mathrm{O}(3 \times 15 \mathrm{~mL})$. The organic phase was successively washed with water and brine, dried over $\mathrm{MgSO}_{4}$, filtered and concentrated in vacuum. The disubstitution product, 1,4-bis-(trimethylstannyl)benzene $\mathbf{4 b}$ was obtained as a colorless solid in 71\% yield; m.p.: $72-74{ }^{\circ} \mathrm{C} ;{ }^{1} \mathrm{H}$ NMR $\left(\mathrm{CDCl}_{3}\right): \delta 7.41\left(\mathrm{~s},{ }^{3} J_{\mathrm{HSn}}=39.5 \mathrm{~Hz}, 4 \mathrm{H}\right)$, $0.22\left(\mathrm{~s},{ }^{2} J_{\mathrm{HSn}}=55.1 / 52.8 \mathrm{~Hz}, 18 \mathrm{H}, \mathrm{SnCH}_{3}\right) ;{ }^{13} \mathrm{C} \mathrm{NMR}: \delta 142.7\left({ }^{1} J_{\mathrm{CSn}}=460.1 / 440.2 \mathrm{~Hz}, \mathrm{C}\right), 136.0$ $\left({ }^{2} J_{\mathrm{CSn}}=42.8 / 33.4 \mathrm{~Hz}, \mathrm{CH}\right),-9.2\left({ }^{1} J_{\mathrm{CSn}}=350.0 / 334.5 \mathrm{~Hz}, \mathrm{SnCH}_{3}\right) ; \mathrm{MS}(m / z$, relative intensity): $389\left(100,\left[\mathrm{M}-\mathrm{CH}_{3}\right]^{+}, \mathrm{Sn}_{2} \text { pattern), } 359 \text { (17, [M-3CH}\right]^{+}, \mathrm{Sn}_{2}$ pattern), 329 (14, [M-5CH$]^{+}, \mathrm{Sn}_{2}$ pattern).

1,3-Bis(trimethylstannyl)benzene (4a). colorless liquid. ${ }^{1} \mathrm{H}$ NMR: $\delta$ 7.30-6.83 (m, 4H), $0.25(\mathrm{~s}$, $\left.{ }^{2} J_{\mathrm{HSn}}=54.8 / 52.6 \mathrm{~Hz}, 18 \mathrm{H}, \mathrm{SnCH}_{3}\right)$; ${ }^{13} \mathrm{C} \mathrm{NMR}: \delta 143.6\left({ }^{2} J_{\mathrm{CSn}}=31.5 \mathrm{~Hz}, \mathrm{CH}\right), 142.4\left({ }^{1} J_{\mathrm{CSn}}=\right.$ $452.5 / 432.5 \mathrm{~Hz}, \mathrm{C}), 136.2\left({ }^{2} J_{\mathrm{CSn}}=36,5 / 11,3 \mathrm{~Hz}, \mathrm{CH}\right) ; 128,4\left({ }^{3} J_{\mathrm{CSn}}=42,4 \mathrm{~Hz}, \mathrm{CH}\right) ;-9,1\left({ }^{1} J_{\mathrm{CSn}}=\right.$ 348,2/332,7Hz, $\left.\mathrm{SnCH}_{3}\right)$; MS (m/z, relative intensity): 389 (100, [M-CH$]^{+}, \mathrm{Sn}_{2}$ pattern), 359 (18, $\left[\mathrm{M}-3 \mathrm{CH}_{3}\right]^{+}, \mathrm{Sn}_{2}$ pattern), $329\left(13,\left[\mathrm{M}-5 \mathrm{CH}_{3}\right]^{+}, \mathrm{Sn}_{2}\right.$ pattern $)$.

1,3,5-Tris(trimethylstannyl)benzene (5). colorless solid; m.p.: 83-85 ${ }^{\circ} \mathrm{C} ;{ }^{1} \mathrm{H}$ NMR: $\delta 7.60$ (s, $3 \mathrm{H}), 0.29\left(\mathrm{~s},{ }^{2} J_{\mathrm{HSn}}=55.2 / 51.9 \mathrm{~Hz}, 27 \mathrm{H}, \mathrm{SnCH}_{3}\right) ;{ }^{13} \mathrm{C} \mathrm{NMR}: \delta 143.6\left({ }^{2} J_{\mathrm{CSn}}=39.8 \mathrm{~Hz}, \mathrm{CH}\right), 142.2$ $\left({ }^{1} J_{\mathrm{CSn}}=449.7 / 389.6 \mathrm{~Hz}, \mathrm{C}\right),-9.8\left({ }^{1} J_{\mathrm{CSn}}=343.4 / 328.1 \mathrm{~Hz}, \mathrm{CH}\right)$; MS ( $m / z$, relative intensity): 551 (100, $\left[\mathrm{M}-\mathrm{CH}_{3}\right]^{+}, \mathrm{Sn}_{3}$ pattern), $521\left(14,\left[\mathrm{M}-3 \mathrm{CH}_{3}\right]^{+}, \mathrm{Sn}_{3} \text { pattern), } 491 \text { (17, [M-5CH}\right]^{+}, \mathrm{Sn}_{3}$ pattern), 389 (8, $\mathrm{Sn}_{2}$ pattern). 


\section{Supplementary Material}

${ }^{1} \mathrm{H}$ and ${ }^{13} \mathrm{C}-\mathrm{NMR}$ spectra of arylammonium salts $\mathbf{2 a}, \mathbf{2 c}-\mathbf{e}, \mathbf{3} \mathbf{a}$ and $\mathbf{3 b}$.

\section{Acknowledgements}

This work was partially supported by CONICET, CIC, ANPCYT and the Universidad Nacional del Sur, Bahía Blanca, Argentina. CONICET is thanked for a research fellowship to GFS.

\section{References}

1. (a) Gielen, M.; Davies, A.; Pannell, K.; Tiekink, E. In Tin chemistry: Fundamentals, Frontiers and Applications; Wiley \& Sons: Chichester, 2008. (b) Davies, A. G. in Organotin Chemistry; VCH: Weinheim, 1997. (c) Sato, T. In Comprehensive Organometallic Chemistry II; Pergamon: New York, 1995; Vol. 8.

2. For a review see: Farina V.; Krishnamurthy V.; Scott W. J. In The Stille Reaction: Organic Reactions; Paquette, L. A. Ed.; John Wiley \& Sons: New York, 1997; Vol. 50.

3. (a) Koo, S.; Liebeskind, L. S. J. Am. Chem. Soc. 1995, 117, 3389. (b) Rot, N.; Bickelhaupt, F. Organometallics 1997, 16, 5027.

4. Wursthorn, K. R.; Kuivila, H. G. J.Organometal.Chem. 1977, 140, 29.

5. Rot, N.; de Kanter, F. J. J.; Bickelhaupt, F.; Smeets, W. J. J.; Spek, A. L. J. Organometal. Chem. 2000, 593-594, 369.

6. (a) Yammal, C. C.; Podestá, J. C.; Rossi, R. A. J.Org.Chem. 1992, 57, 5720. (b) Córsico, E. F.; Rossi, R. A. Synlett 2000, 227.

7. (a) Chopa, A. B.; Lockhart, M. T.; Silbestri, G. F. Organometallics 2000, 19, 2249. (b) Chopa, A. B.; Lockhart, M .T.; Silbestri, G. F. Organometallics 2001, 20, 3358. (c) Chopa, A. B.; Lockhart, M. T.; Silbestri, G. F. Organometallics 2002, 21, 5874; (d) Chopa, A. B.; Lockhart, M. T.; Dorn, V. B. Organometallics, 2002, 21, 1425; (e) Chopa, A. B.; Dorn, V. B.; Badajoz, M. A.; Lockhart, M. T. J. Org .Chem. 2004, 69, 3801; (f) Dorn, V. B.; Badajoz, M. A.; Lockhart, M. T.; Chopa, A .B.; Pierini, A. B. J. Organometal. Chem. 2008, 693, 2458.

8. (a) Sommer, H. Z.; Jackson, L. L. J. Org. Chem. 1970, 35, 1558. (b) Sommer, H. Z.; Lipp, H. I.; Jackson, L. L. J. Org. Chem. 1971, 36, 824. (c) Giumanini, A. G.; Chiavari, G.; Musiani, M. M.; Rossi, P. Synthesis 1980, 743.

9. Identified by comparison with an authentic sample prepared by a known procedure (see Refs. 7a,d)

10. For reviews see: (a) Bowmam, W. R. Chem. Soc. Rev. 1988, 17, 283. (b) Norris, R.K. in Comprehensive Organic Synthesis; Trost, B. M., Ed.; Pergamon: New York, 1991; Vol. 4, p. 
451. (c) Rossi, R. A.; Pierini, A. B.; Santiago A. N. Aromatic Substitution by $S_{R N} 1$ Reaction: Organic Reactions; Paquette, L. A., Brittman, R., Eds.; Wiley: New York, 1999; Vol. 54, p.1. (d) Rossi, R. A.; Pierini, A. B.; Peñeñory, A. B. Chem. Rev. 2003, 103, 71.

11. The crude mixtures were treated with deuterium oxide and, after filtration, ${ }^{13} \mathrm{C}-\mathrm{NMR}$ spectra were recorded

12. Kudo, K.; Shibata, T.; Kashimura, T.; Mori, S.; Sugita, N. Chem. Lett. 1987, 577.

13. Konovalov, V. V.; Bilkis, I. I.; Selivanov, B. A.; Shteingarts, V. D.; Tsvetkov, Y. D. J. Chem. Soc., Perkin Trans. 2 1993, 10, 1707.

14. Saigo, T. Polishing solutions. Jpn. Kokai Tokkyo Koho JP 2010080864 A 20100408, 2010.

15. For iodide see: Loehr, H. G.; Engel, A.; Josel, H. P.; Voegtle, F.; Schuh, W.; Puff, H. J. Org. Chem. 1984, 49, 1621.

16. For iodide see: Fraenkel, G.; Kim, J. P. J. Am. Chem. Soc. 1966, 88, 4203. 